\title{
The Income Tax Exemption and Charities: China and the United States Compared
}

\author{
Yiling Lu \\ Business school, Hohai University, Jiangning, Nanjing, China
}

Keywords: charitable donation; tax preference policy; comparison between Chinese and the United States;

\begin{abstract}
Charitable donation is an important part of socio-economic redistribution. Although people's willingness to donate to the poor has gradually increased with economic development, the soil of charity is still not fertile in China. This paper mainly focuses on this problem from the perspective of tax preferences. By comparing the current situation of philanthropy and relevant tax preference policy in China and the United States, this paper analyzes the reasons why people's charity will is not stimulated, and it proposes improvements on tax policy to promote the development of philanthropy.
\end{abstract}

\section{Comparison of Charitable Donations between China and the United States}

According to the 2017 China Charitable Contributions Report released by China Charity Alliance on September 21, 2018, China received a total value of 149.986 billion yuan in donations from home and abroad in 2017, accounting for $0.18 \%$ of the country's GDP. Among this, donations from enterprises and individuals totaled 96.334 and 34.917 billion yuan, accounting for $64.23 \%$ and $23.28 \%$ separately. In the same period, annual U.S. charitable donations amounted to $\$ 410$ billion, or about RMB 268.1851 billion, which is about 18 times the total amount of China. And the annual U.S. charitable donations account for $2.1 \%$ of GDP, which is 12 times that of China. The gap in the total amount is even more significant reflected in the contribution per person. Per capital donation of China is 107.90 yuan while that of United States was 872 dollars, or RMB 5,978, which is more than 55 times of the data of China. The source composition of U.S. charitable donations is also very different from that of China. In America, donations from individuals account for 70 per cent of the total number. Apart from the differences in the gross national economy and the differences in the per capital income, there is still a significant gap in philanthropy between the two countries. In addition to the important factor that is religious culture, the differences in tax preference policy between the two countries can also be part of the reason.

\section{Differences Between the Tax Preferential Systems of China and the United States}

The existing tax laws for the development of charity in China mainly refer to Individual Income Tax Law of the People's Republic of China (Adopted at the Third Meeting of the Fifth National People's Congress on September 10th, 1980) and Law of the People's Republic of China on Enterprise Income Tax adopted in 2008. For different income objects, specific provisions can be divided into three categories:

For charitable organizations, certified charitable organizations may exempt or reduce enterprise income tax when accepting donations from other units, individuals or eligible government subsidies.

For individuals and enterprises that donate, donations within certain percentage can be deducted from individual income tax and enterprise income tax.

For beneficiaries of charity payments or services, state relief payments for instance, are exempted from individual income tax. Individual income tax on incomes of the disabled, the lonely elderly, family members of martyrs, and income approved by other financial department can also be reduced or exempted.

Among the categories above, the second one is the most relevant to donor incentives. The details 
are as follows:

When calculating the amount of income taxable, an enterprise may deduct its expenses incurred for donation out of public welfare, provided that the portion involved is not more than 12 percent of the total amount of its annual profits. This is updated and revised on February 24, 2017, that the excess of $12 \%$ can be carried forward within the next three years.

If personal income is donated to education and other social welfare undertakings, social disasters and poverty-stricken areas through social organizations and state organs in China, the portion that does not exceed $30 \%$ of taxable income can be deducted.

The targets of tax reduction and exemption in different countries are almost the same, but the difference between the standard and the percentage of exemption is obvious enough to produce a disparity in stimulates among the people. In the United States, the tax law provides that a business or organization can deduct no more than $10 \%$ of its annual income before paying income tax, and the excess may be carried forward sits in subsequent years for a period of 5 years. Compared with the limit of $12 \%$ of profits for Chinese companies, US companies can deduct no more than $10 \%$ of income, which is particularly forgiving, and the time limit for carrying forward is longer. What is more, corporate donations are not restricted within currency, securities, equity, trust, etc. can also be used as forms of donation. There is also a detailed reference on how to measure donation. In the case of individual contributions, $50 \%$ of eligible contributions can be deducted before tax and the excess can be carried forward over the next 5 years. Both figures also go well beyond those of China, achieving institutional goals to promote charitable donations of residents. And in the United States, if you donate through estate, the deduction ratio can reach $100 \%$ [1]. That is why many of America's billionaires are willing to contribute a large portion of their assets to charity, or even willing to make an all-out donation. With a harsh rate of 50 per cent at most of inheritance tax, the generosity of people will be inspired to the greatest extent [2]. The difference between American corporate and individual charity tax incentives also explains why $70 \%$ of the total US charitable donations comes from individuals, because the tax law for individual preferential tax rates is much higher than that of corporations. All data analysis points to the conclusion that the incentive effect of tax policy preferences on willingness of people to donate is obvious and absolute.

\section{Defects of China's Existing Tax Preferential Policies}

Through comparison with the policies of the United States, China's preferential tax policies have the following problems:

The qualifications of charities are difficult to obtain, and tax preferences are difficult to implement [3].

Before a charity organization becomes a formal one, it needs to be approved by relevant government departments. The entire approval process requires the cooperation of departments of civil affairs, taxation, finance and other. However, a standardized reference process has not yet been formed, and the process is laborious with a lack of efficient cooperation among all parties. In actual operation, the Ministry of Civil Affairs often lacks participation. Out of the guarantee of taxation, the tax department usually sets high standards for charities, making it difficult to obtain institutional qualifications for charity organizations. Sometimes the masses really want to participate in charity, but there is no charity institution as a channel. Regulating the procedures for obtaining the qualifications and coordinating inter-departmental work will greatly help public welfare undertakings.

Tax relief is based on a single form of contribution

China now has a clear tax reduction and exemption policy for donations in the form of currency but there are still a lot of gaps left in the law in other forms of assets such as equity, securities, fixed assets, intellectual property, etc.[4] Tax incentives for equity donations are a typical case. In 2003, the Ministry of Finance issued the Circulars on Strengthening the Financial Administration of the Donations Made by Enterprises, and it clearly states that 'The equity and credit held by the enterprise shall not be used for external donations'. In 2009, Notice of the Ministry of Finance on Financial Issues Concerning Charitable Donations of Shareholdings by Enterprises was announced, 
and it allowed corporate donations to hold the same equity interests as public welfare undertakings, but no supporting preferential tax policies for equity donations were introduced. This kind of uncertainty held people with generosity behind the sidelines.

Taxes on real estate donations are also high. In 2001, an elderly couple in Shanghai, Li Qingquan and Tang Meijun, were going to donate their house worth about 3 million yuan in Xujiahui area by will. However they were rejected by several charities for various reasons, including complicated procedures and exhausting tax systems. Finally, the Xuhui Branch of Shanghai Charity Foundation accepted the donation after the relevant taxes and fees were exempted through the 'special handling'. Due to the complexity of property donation procedures which cover notarization, transfer and auction, the entire process requires the participation of multiple relevant departments, and the costs will be deducted from the property value in the form of tax [5]. Not only that, when the property ownership is submitted to the charity, the beneficiary still needs to pay deed tax, warrant stamp tax, registration fee and other fees. If the beneficiary wants to sell the donation at a price higher than when accepted and thus benefit from the price difference to serve public welfare purposes, the payment of land value-added tax, enterprise income tax, corporate real estate tax, land use tax, transaction fee and other taxes and fees is still inevitable. In a house worth 3 million yuan, the total taxes and fees generated during the entire donation and benefit process can amount to nearly one million yuan. Initial energy to devotion to charity of donors was undermined by high rates during operation. What was supposed to be instructive and encouraging among awaiting warm hearts fades into tiring work. In order to maximize the value of donated goods, government departments should first reduce the various tax rates corresponding to real estate used for charitable donations during the transfer process, and secondly, reduce or exempt the appropriate amount of VAT, corporate income tax, transaction fees, etc. when charities are selling. In addition, it is especially important to improve the administrative efficiency in the whole process, which can reduce the generation of spare expenses and create a heart-warming situation where 'the people are willing to donate and the institutions are willing to receive'.

\section{Tax Preferential Policy Improvement Measures}

In order to solve the existing defects of China's preferential tax policies, combined with China's actual situation, the following improvements should be made.

Increase the tax deductible amount and extend the carry-over period. Looking at the support of the public welfare of the developed countries in the international scope in terms of the deductible tax of individual income tax: $40 \%$ deductible in France, 50\% in the United States and Canada even up to $77 \%$. The figure for China is only $30 \%$, which is relatively low. Also in China, the amount of donations that enterprises exceed the limit can be carried forward for 3 years, and individual income tax cannot be carried forward. However, in the United States, carry-over period can be up to 5 years, and 7 years in Germany. China should learn from these developed countries, increase the deductible ratio, extend the carry-over period, and guide the public to invest in public welfare undertakings as individuals.

Improve the tax preferential system beyond currency donations. At present, the preferential treatment of donations in China is mainly focused on monetary funds. In the next stage, we should formulate different preferential tax rates, different levels, comprehensive scope, and strong implementable public welfare taxation systems for various forms of public welfare donations according to the actual situation in China [6]. And China should encourage real estate donations, support shares, securities and other forms of donations.

Simplify and standardize the procedures for obtaining qualifications of charities, so as to achieve efficient communication and cooperation between departments. It can encourage the establishment of charities with different service targets and various forms of charity. Let the preferential tax policies for charities be implemented, and then guide the enthusiasm of the public for charity.

Build an easy-to-use online deduction system to simplify the connection between charity and practice. In order to truly record the amount of charitable donations of individuals and enterprises, and to facilitate the calculation and later verification of the deductions in income tax, a real-name 
donation network information system should be constructed to inform every donation in real life. Each piece of information not being repeated or missed ensures that each donation has a clear source and destination.

\section{Conclusion}

Taxation is an important finger of the 'visible hand' [7] and a tool used by government to distribute civil wealth. Under previous general situation of making way for economic development, it is reasonable that the tax law does not show a preference for charity. The essence of tax reduction for charity is to sacrifice part of the fiscal tax revenue and lead the funds into poor and less developed areas to achieve common prosperity [8]. However, with poverty alleviation as the background of today, the government should be more fully aware that charity is the spontaneous poverty alleviation of the people. Charity is a way to reduce government intervention and allow funds and goods to flow directly from the richer to the poorer. Taking full advantage of tax as a tool will help encourage people to actively engage in charity, support public welfare, thus realizing the aim of a narrowed gap between urban and rural living standards, and furthermore common prosperity.

\section{References}

[1] Shuo, W., Lanying D., Yike Y. (2019) Analysis of the Impact of Taxation on Charitable Donations under the self-Interest Motive of Enterprises. Tax Research, (07):96-100.

[2] Hang Jung, K. (2016) A Legal Review of Charity Care and Tax Exemption in the United States. Tax and Law, 9 (2):1-38.

[3] Lifei, W. (2017) Research on China's Charitable Donation Tax Preferential Policies from a Comparative Perspective between China and the United States. Tianjin: Tianjin University of Finance and Economics,

[4] Lei, L., Yongqiang Z. (2017) Research on the China-US Charitable Donation Credit Personal Income Tax System. International Tax, (12):67-70.

[5] Yanjie, L. (2016) Evaluation and Prospect of China's Charity Tax Relief System—-Research on the Background of Charity Legislation. Journal of Beijing University of Aeronautics and Astronautics (Social Science Edition), (01):66-75.

[6] YuCheng, Z. (2019) Research on Tax Incentive Policy of Charitable Donations. Anhui: Anhui University of Finance and Economics,

[7] John, M. K. (1936) The General Theory of Employment, Interest and Money,

[8] Joan, M. Y. (2000) The Charity Property -Tax Exemption Special Political Issues Concerning Property Tax Extempytions for Charities. Proceedings. Annual Conference on Taxation and Minutes of the Annual Meeting of the National Tax Association, (93):164-169. 